\title{
STUDY ON BOVINE SUB-CLINICAL MASTITIS ON FARM CONDITION WITH SPECIAL EMPHASIS ON ANTIBIOGRAM OF THE CAUSATIVE BACTERIA
}

\author{
M. T. $\operatorname{Hasan}^{1 *}$, M. R. Islam ${ }^{1}$, N. S. Runa ${ }^{2}$, M. N. $\operatorname{Hasan}^{4}$, A. H. M. M. Uddin ${ }^{3}$ and S. K. Singh ${ }^{1}$ \\ ${ }^{1}$ Department of Medicine, ${ }^{2}$ Department of Pathology, ${ }^{3}$ Department of Surgery and Theriogenology, Faculty of \\ Veterinary and Animal Science, Sylhet Agricultural University, Bangladesh; ${ }^{4}$ Department of Pharmacology, \\ Faculty of Veterinary Science, Bangladesh Agricultural University, Mymensingh-2202, Bangladesh
}

\begin{abstract}
The study was conducted to find out the prevalence of sub-clinical mastitis (SCM) and antibiogram of the causative bacteria in dairy cows at the Sylhet govt. Dairy Farm (SGDF) and Local Farms of Sylhet (LFS) during the period of July2014 to June2015. These farms were selected to assess the predominant types of bacteria involved in causing sub-clinical mastitis and to know the in vitro antibiotic sensitivity spectrum of these bacterial isolates against the commonly used antibiotics and to study the economic effects due to SCM. Use of California Mastitis Test (CMT) for the detection of sub-clinical mastitis showed 42out of 100 samples were test positive, among which +(Trace) 22.0\%, ++(Distinct) 12.0\%, +++(Strong) 3.0\%, \pm (Doubtful) 5.0\%. Bacteriological examination of milk samples of 100 milch cows (400 quarters) revealed that 42 cows (42.0\%) had suffering from SCM with different bacterial infection with 95\% confidence limit was 32.1574-51.8426. Among 42 positive samples31 (31.0\%) cows had mono-bacterial infection and 11 (11.0\%) cows had mixed bacterial infections. Statistical analysis of the result of single and mixed bacterial infections in the milk of apparently healthy milch cows revealed that the single infection was significantly $(\mathrm{P}<0.05)$ higher than mixed bacterial infection. Of the 31 mono-bacterial isolates, of which 23 (23.0\%) isolates were Staphylococci, 3 (3.0\%) isolates were Escherichia coli, 5 (5.0\%) isolated Streptococcus spp. The 11 cows had mixed infection, of which 5 had Staphylococcus spp. + Streptococcus spp., 3 had E. coli + Staphylococcus spp., and 3 had Streptococcus spp. + E. coli. Of 42 positive cases of SCM Staphylococcus spp. isolated from 23 samples. Among these 23 positive samples 13 obtained from SGDF (37.14\%) and 10 obtained from LFS (15.38\%). Escherichia coli isolated from 3 samples. Among these 3 positive samples 3 obtained from LFS (4.62\%). Streptococcus spp. isolated from 5 samples. Among these 5 positive samples 1 obtained from SGDF (2.86\%) and 4 obtained from LFS (6.15\%). Ceftriaxone, ciprofloxacin and gentamicin were the best drug for treating sub-clinical mastitis.
\end{abstract}

Key words: Bovine sub-clinical mastitis, prevalence, antibiogram.

\section{INTRODUCTION}

Mastitis is an inflammatory condition of the mammary gland, characterized by changes in the physical characteristics of the udder or milk (Nazifi et al., 2011). Mastitis can be classified into three major types: clinical mastitis (CM), sub-clinical mastitis (SCM) and chronic mastitis (ChM) (Anonymous, 2003). In CM, there is swelling, heat, pain, and indurations observed in the mammary gland and also changes in milk color, clots are present in the milk and there are large numbers of leukocytes in the milk (Sharma and Maiti, 2010). In SCM, there are no gross inflammatory changes in the udder tissue and no changes physical appearance on milk. Only increased somatic cell count (SCC) in the milk, the presence of pathogenic organisms in the milk, and an inflammatory response that can only be detected by screening tests such as California Mastitis Test (CMT), White Side Test (WST), Surf Field Mastitis Test (SFMT) (Sachin and Suresh, 2006; Madut et al., 2009). In ChM, udder becomes hard due to fibrosis, the quarters may become thickened, firm, nodular and atrophic. The milk may appear as yellowish fluid or white with clots and flakes. Sometimes it may look as green or yellowgreen and foul smelling (Chakrabarti, 2007). The sub-clinical form of mastitis in dairy cows is important because this form is (a) 15 to 40 times more prevalent than the clinical form, (b) it usually precedes the clinical form, (c) it is of long duration, (d) it is difficult to detect, (e) It reduces milk production, and (f) it adversely affects milk quality (Seegers et al., 2003). It is now a well-known fact that the SCM is more serious and is responsible for much greater loss to the dairy industry in Bangladesh (Kader et al., 2003).There are also economic losses in dairy farms due to (a) reduction in milk production, (b) discarding abnormal milk and milk withheld from cows treated

*Corresponding e-mail address: hasan.tanvir27@gmail.com 


\section{T. Hasan and others}

with antibiotics, (c) degradation of milk quality and price due to high bacterial presence or SCC, (d) costs of drugs, (e) veterinary services and increased labor costs, (f) increased risk of subsequent mastitis, (g) herd replacement, and (h) problems related to antibiotics residues in milk and its products (Bramely, 1996).The prevalence of sub-clinical mastitis in milch cow has been reported to be $15.8 \%$ with California Mastitis Test (CMT) from Baghabarighat, Sirajgonj district by Prodhan et al. (1996). Rahman et al. (2009) reported that the prevalence of bovine SCM as $19.9 \%$ and $44.8 \%$ in dry \& wet seasons, respectively at Sirajgonj districts. There also found the prevalence of SCM was $43.3 \%$ in Sylhet Govt. dairy farm and $53.1 \%$ in local dairy farms, respectively in Sylhet district (Rahman et al., 2010). The CM can easily be detected by inspection of udder or systemic signs of inflammation, whereas, diagnosis of SCM is more problematic since the milk appears normal but usually has an elevated somatic cell count (Islam et al., 2010). Various methods, based on physical and chemical changes of milk and cultural isolation of organisms, are used for diagnosis of SCM. Therefore, indirect tests such as CMT, WST, SFMT etc. can be used which are simple and do not require any complex laboratory equipment. The CMT and SCC are arguably the only reliable cow side screening tests for SCM that can easily be applied. The CMT is a simple, inexpensive, rapid screening test for SCM, based upon the amount of cellular nuclear protein present in the milk sample. CMT showed better performance in detecting SCM (37.58\%) among three indirect tests used WST (36.67\%) and SFMT (35.15\%) (Islam et al., 2010).Various indirect tests have been described (Schalm et al., 1971) to detect the SCM, but each test has got some limitations as it fails to detect SCM at all stages. The somatic cell count and bacterial load count (BLC) are two methods accepted reliably for detecting the early infection (Schalm et al., 1971). The efficacy of antibiotic therapy for intramammary infections (IMIs) early in lactation is scarce and few, with the ones carried out reporting mixed results. Rosenberg et al., (2002) evaluated the response to therapy with intramammary (IMM) Cephapirin Sodium on CMT positive quarters in lactating cows on cure rates and SCC. It was determined that by the 4-week postcalving evaluation, quarters treated with Cephapirin Sodium had significantly increased cure rates, and SCC were significantly reduced. Wallace et al. (2004) also randomly assigning cows with CMT-positive quarters to receive either IMM Cephapirin Sodium or no treatment, found that there was no difference in cure rates for IMM antibiotic-treated quarters for major pathogens compared to the untreated cows. However, there was an advantage for cure rates using antibiotics against environmental streptococcal infections. Quarters with streptococci infections were 3.5 times more likely to cure if treated with Cephapirin Sodium. A field studies have found that IMM antibiotic therapy was beneficial for Gram-positive organisms and coagulase-negative staphylococci, but ineffective for Gram-negative organism (Roberson et al., 2004), because Gram-negative bacteria tend to have a more complex layering in their cell wall structure (Beveridge, 1999).

Additionally, the advent of postmilking teat antisepsis has been important in contributing to decreasing contagious IMI. Teats were dipped after milking and cows were treated with penicillin-dihydrostreptomycin at dry-off, IMI caused by major mastitis pathogens decreased by $75 \%$ and $45 \%$, respectively. Post-dipping alone has been estimated to decrease the rate of new IMI by 50\% (Nickerson and Boddie, 1997). Antimicrobials are the most important tool in SCM control programs in cows. But there are not properly known by dairy farmers to infuse of intramammary antibiotics in SCM affected lactating cows. However, the reports on the efficacy of intramammary infusion in lactating cows are very limited and the information on the prevalence of SCM in the area is lacking or very less. The main objectives of the research are to isolate and identify the causative bacteria involved in sub-clinical mastitis and in-vitro antibiotic sensitivity test of the bacteria and to know the economic effect of sub clinical mastitis in Dairy cows.

\section{MATERIALS AND METHODS}

The research work was conducted in the Department of Medicine and the laboratory of Microbiology and Immunology, Sylhet Agricultural University, Sylhet, during the period of July2014 to June2015. Study was conducted on Sylhet govt. Dairy Farm (SGDF) and Local Farms of Sylhet (LFS).A total number of thirty (35) apparently healthy milch cows of the SGDF and Sixty five (65) milch cows of LFS were randomly selected for this study. Before taking the milk sample, a teatful of milk was milked into a tube and later discarded. This was to flush out any bacteria that might be present in the teat canal. The teat and teat tips were disinfected with a swab soaked in $70 \%$ alcohol. Milk samples were collected aseptically from the udder at the time of morning milking. All the milk collected vials were labeled with the identification number of cow (and others symbol).Immediately after collection the samples were subjected to CMT. 
Each milk sample was stained with Gram's Method and was examined under microscope as described by Samad (1996). The findings were recorded and then the samples which were found positive for bacteria used for the isolation and identification of bacteria. Each of the collected milk samples was kept in the incubator at $37^{\circ} \mathrm{C}$ for 24 hours and then stained with Gram's Method as described by Samad (1996). The samples which were found positive for bacteria were selected for the isolation of the organisms. Cultural media were used for the isolation and identification of the bacteria were, Nutrient Broth (Hi media, India), Blood agar media (Hi Media Lab. Pvt. Ltd., Bombay), EMB agar (EMB, Oxiod, UK), Mannitol-salt agar (Hi media, India), Muller Hinton Agar (MHA).

\section{Statistical analysis}

Data was analyzed with SAS version 9.4. A95\% Confidence Limits for prevalence percent was estimated.

\section{RESULTS AND DISCUSSION}

Milk samples from 35 milch cows of SGDF (140 quarters), Sylhet and from 65 milch cows of different LFS (260 quarters), were randomly collected aseptically and examined bacteriologically, of which SGDF showed 15 (42.86\%) with 95\% Confidence Limits 25.6095-60.1048, Home Fresh Dairy Farm 14 (70\%) limit 47.995792.0043, Baby Dairy Farm 4 (20\%) limit 0.7931-39.2069 , Bulbul Dairy Farm 5 (33.33\%) limit 6.3116-60.3551, Rahman Dairy Farm 4 (40\%) positive SCM limit 3.0591-76.9409. Highest prevalence of SCM was recorded in milch cows of Home Fresh Dairy Farm, which is $70 \%$. Overall prevalence of sub-clinical mastitis was found 42\% with 95\% confidence limits 32.1574-51.8426(Table 1).

Use of California Mastitis Test (CMT) for the detection of sub clinical mastitis showed 42 samples were test positive out of 100, among which +(Trace) 22.0\%, ++(Distinct) 12.0\%, +++(Strong) 3.0\%, \pm (Doubtful) $5.0 \% .48$ samples were negative showed in (Table 2).

Table 1. Distribution of sub-clinical mastitis in Sylhet govt. dairy farm and local farms of Sylhet

\begin{tabular}{|c|c|c|c|c|c|c|}
\hline & Sources & $\begin{array}{l}\text { Total no. of } \\
\text { cows tested }\end{array}$ & $\begin{array}{c}\text { Test } \\
\text { positive }\end{array}$ & $\begin{array}{c}\text { Test negative } \\
\text { sample }\end{array}$ & $\begin{array}{c}\text { Prevalence of } \\
\text { SCM (\%) }\end{array}$ & $\begin{array}{l}\text { 95\% Confidence } \\
\text { limits }\end{array}$ \\
\hline SG & (Sylhet Govt. Dairy Farm) & 35 & 15 & 20 & 42.86 & $25.60-60.10$ \\
\hline \multirow{5}{*}{ LFS } & Home Fresh Dairy Farm & 20 & 14 & 06 & 70 & $47.99-92.00$ \\
\hline & Baby Dairy Farm & 20 & 4 & 16 & 20 & $0.79-39.20$ \\
\hline & Bulbul Dairy Farm & 15 & 5 & 10 & 33.33 & 6.31-60.35 \\
\hline & Rahman Dairy Farm & 10 & 4 & 06 & 40 & 3.06-76.94 \\
\hline & Total & 100 & 42 & 48 & 42 & $32.16-51.84$ \\
\hline
\end{tabular}

Table 2. Use of California Mastitis Test (CMT) for the detection of sub-clinical mastitis in dairy cows

\begin{tabular}{ccccc}
\hline Test & Total sample & Nature of reaction & No. of sample reacted & Percentage (\%) \\
\hline & & + (Trace) & 22 & 22.0 \\
California & \multirow{3}{*}{100} & $++($ Distinct) & 12 & 12.0 \\
Mastitis Test & & $+++($ Strong) & 3 & 3.0 \\
(CMT) & & \pm (Doubtful) & 5 & 5.0 \\
& & -(Negative) & 48 & 48.0 \\
\hline
\end{tabular}

Bacteriological examination of milk samples of 100 milch cows (400 quarters) revealed that 42 cows (42.0\%) had suffering from SCM with different bacterial infection, of which 31 (31.0\%) cows had mono-bacterial infection and $11(11.0 \%)$ cows had mixed bacterial infections (Table4). Statistical analysis of the result of single and mixed bacterial infection in the milk of apparently healthy milch cows revealed that the single infection was significantly $(\mathrm{P}<0.05$ ) higher than mixed bacterial infection (Table 3). Of the 31 mono-bacterial isolates, of which 23 (23.0\%) isolates were Staphylococci, 3 (3.0\%) isolates were Escherichia coli, 5 (5.0\%) isolated Streptococcus spp. (Table 3). The 11 (11.0\%) cows had mixed infection, of which 5 (5.0\%) had Staphylococcus spp. + Streptococcus spp., 3 (3.0\%) had E. coli + Staphylococcus spp., and 3 (3.0\%) had Streptococcus spp. + E. coli. Among 42 positive cases of SCM Staphylococcus spp. isolated from 23 samples. Among these 23 positive 


\section{T. Hasan and others}

samples 13 obtained from SGDF (37.14\%) and 10 obtained from LFS (15.38\%). Escherichia coli isolated from 3 samples. Among these 3 positive samples 3 obtained from LFS (4.62\%). Streptococcus spp. isolated from 5 samples. Among these 5 positive samples 1 obtained from SGDF (2.86\%) and 4 obtained from LFS (6.15\%). Of the 11 mixed infections, 5 were Staph. + Strep. Among these 5 positive samples 1 obtained from SGDF (2.86\%) and 4 obtained from LFS (6.15\%). Staph. + E. coli obtained from LFS that is 3 (4.62\%). Strep. + E. coli combination obtained from 3 samples also from LFS. The overall mean milk yield of dairy cows who had bacterial infection (SCM) reduce from 7.7 litre to 6.2 litre i.e. - 1.50 litre/cow/day (Table 3).

Table 3. Etiology and effects of sub-clinical mastitis on milk production in dairy cows

\begin{tabular}{|c|c|c|c|c|c|c|c|c|}
\hline \multirow{2}{*}{$\begin{array}{c}\text { Sl } \\
\text { No. }\end{array}$} & \multirow[t]{2}{*}{ Organisms isolated } & \multirow[b]{2}{*}{ Farms } & \multirow{2}{*}{$\begin{array}{l}\text { No. of } \\
\text { cows } \\
\text { tested }\end{array}$} & \multicolumn{2}{|c|}{ Positive } & \multicolumn{3}{|c|}{ Mean milk yield (L/cow/day) } \\
\hline & & & & No. & $\%$ & $\begin{array}{l}\text { Pre-testing } \\
\text { records }\end{array}$ & $\begin{array}{l}\text { Records at } \\
\text { testing time }\end{array}$ & Difference \\
\hline \multirow{4}{*}{01} & \multirow{4}{*}{ Staphylococcus spp. } & SGDF & 35 & 13 & 37.14 & 5.5 & 4.7 & -0.8 \\
\hline & & LFS & 65 & 10 & 15.38 & 10.5 & 7.8 & -2.70 \\
\hline & & Single & 100 & 23 & 23 & 8 & 6.25 & -1.75 \\
\hline & & SGDF & 35 & 0.00 & 0.00 & 0.00 & 0.00 & \\
\hline \multirow[t]{2}{*}{02} & \multirow[t]{2}{*}{ Escherichia coli } & LFS & 65 & 03 & 4.62 & 11.2 & 8.5 & -2.70 \\
\hline & & SGDF & 35 & 01 & 2.86 & 4.5 & 4.1 & -0.40 \\
\hline \multirow[t]{3}{*}{03} & \multirow[t]{2}{*}{ Streptococcus spp. } & LFS & 65 & 04 & 6.15 & 9.6 & 7.1 & -2.50 \\
\hline & & Single & 100 & 05 & 05 & 7.05 & 5.6 & -1.45 \\
\hline & & SGDF & 35 & 01 & 2.86 & 4.5 & 4.2 & -0.30 \\
\hline \multirow[t]{3}{*}{04} & \multirow[t]{3}{*}{ Staph. + Strep. } & LFS & 65 & 04 & 6.15 & 10.3 & 7.5 & -2.80 \\
\hline & & Mixed & 100 & 05 & 05 & 7.4 & 5.85 & -1.55 \\
\hline & & SGDF & 35 & 0.00 & 0.00 & 0.00 & 0.00 & \\
\hline \multirow[t]{2}{*}{05} & \multirow[t]{2}{*}{ Staph. + E. coli } & LFS & 65 & 03 & 4.62 & 10.5 & 9.5 & -1.00 \\
\hline & & SGDF & 35 & 0.00 & 0.00 & 0.00 & 0.00 & \\
\hline \multirow[t]{2}{*}{06} & \multirow[t]{2}{*}{ Strep. + E. coli } & LFS & 65 & 03 & 4.62 & 11.2 & 8.7 & -2.50 \\
\hline & & SGDF & 35 & 15 & 42.86 & 4.8 & 4.3 & -0.50 \\
\hline \multirow[t]{2}{*}{07} & \multirow[t]{2}{*}{ Total } & LFS & 65 & 27 & 41.54 & 10.6 & 8.1 & -2.50 \\
\hline & & Overall & 100 & 42 & 42 & 7.7 & 6.2 & -1.50 \\
\hline
\end{tabular}

Among all the bacterial isolates, each of ten (10) isolates of Staphylococcus spp. Streptococcus spp. E. coli were selected randomly for the antibiotic sensitivity and resistance pattern against commonly used antibiotic. The result of sensitivity against antibiotics discs (zone of inhibition) were categorized as resistance (-), less sensitive $(+)$, moderately sensitive $(++)$, highly sensitive $(+++)$. The results of antibiotics sensitivity are given in the (Table4). From the antibiotic sensitivity test of sub-clinical mastitis, it was found that $30 \%$ of the isolated Staphylococcus spp. was moderately sensitive and $70 \%$ were highly sensitive to gentamicin. $30 \%$ of the isolates were moderately sensitive and $70 \%$ were highly sensitive to ciprofloxacin. The organisms showed that $30 \%$ were less sensitive and $70 \%$ were moderately sensitive to erythromycin. Among the isolates, $70 \%$ were resistance and $30 \%$ were less sensitive to ampicillin. The organisms showed that $70 \%$ were resistance and $30 \%$ were less sensitive to amoxicillin. Among the isolates, $30 \%$ were moderately sensitive and $70 \%$ were highly sensitive to ceftriaxone (Table 4). The different isolates of Staphylococcus spp., Streptococcus spp., and E. coli showed identical results in different biochemical tests including sugar fermentation, catalase, methyl red, vogesproskauer (VP) and indole test. Variability on the frequency distributions of different species of bacterial isolates in different milk samples was found. Results of the present study indicate that all the three different types of bacteria were not present in the same milk sample collected from the mastitic cows. Staphylococcus spp. has been isolated as the main pathogens of mastitic cows. This finding is in agreement with the earlier reports made by Gupta et al. (1992), Jha et al. (1994), Boscos et al. (1996), Tuteja et al. (1993), Misra et al. (1903), Shike et at. (1998), Goswami et al. (2002), Seyoum et al. (2003), Saxena et al. (1993) with slight variation. In the antibiotic sensitivity test showed that $30 \%$ of the isolated Streptococcus spp. was moderately sensitive and $70 \%$ were highly sensitive to gentamicin. $30 \%$ of the isolates were moderately sensitive and $70 \%$ were highly sensitive to ciprofloxacin. The organisms showed that $30 \%$ were less sensitive and $70 \%$ were moderately sensitive to 
erythromycin. Among the isolates, $70 \%$ were resistance and 30\% were less sensitive to ampicillin. The organisms showed that $100 \%$ were resistance to amoxicillin. Among the isolates $30 \%$ were moderately sensitive and $70 \%$ were highly sensitive to ceftriaxone.

It was found that $30 \%$ of the isolated Escherichia coli were moderately sensitive and $70 \%$ were highly sensitive to gentamicin. Among the isolates, $30 \%$ were moderately sensitive and $70 \%$ were highly sensitive to ciprofloxacin. The organisms showed $70 \%$ were moderate sensitive and $30 \%$ were highly sensitive to erythromycin. The isolates showed that $30 \%$ were moderately sensitive and $70 \%$ were less sensitive to ampicillin. The isolates showed that $70 \%$ were less sensitive and $30 \%$ were resistant to amoxicillin. The organisms showed that $30 \%$ were moderate sensitive and $70 \%$ were highly sensitive to ceftriaxone. From the study we observed ceftriaxone, ciprofloxacin and gentamicin are the best drug for treating sub-clinical mastitis, though these antibiotics showed maximum sensitivity to the organism responsible to cause sub-clinical mastitis. The results of isolation, identification, biochemical test, frequency distribution and antibiotic sensitivity of the bacteria isolated from milk of sub-clinical mastitic cows in the present study, indicated that the microbial factors play an important role for the development of mastitis. Detailed further epidemiological study requires about the extrinsic and intrinsic factors, which might have direct or indirect influence on the development of mastitis in association with microbes, are required.

Table 4. Results of antibiotic sensitivity tests of the isolated bacteria obtained from milk samples

\begin{tabular}{|c|c|c|c|c|c|c|c|}
\hline \multirow{2}{*}{$\begin{array}{l}\text { Name of bacteria } \\
\text { (No of isolates) }\end{array}$} & \multirow[t]{2}{*}{ Sensitivity } & \multicolumn{6}{|c|}{$\%$ of isolated strains sensitive to various antibiotics } \\
\hline & & GN & CIP & AMP & AMX & CTR & ERY \\
\hline \multirow{4}{*}{$\begin{array}{l}\text { Staphylococcus spp. } \\
(\mathrm{n}=10)\end{array}$} & Resistance & 00.00 & 00.00 & 70.00 & 70.00 & 00.00 & 00.00 \\
\hline & Less sensitive & 00.00 & 00.00 & 30.00 & 30.00 & 00.00 & 30.00 \\
\hline & $\begin{array}{l}\text { Moderate } \\
\text { sensitive }\end{array}$ & 30.00 & 30.00 & 00.00 & 00.00 & 30.00 & 70.00 \\
\hline & Highly sensitive & 70.00 & 70.00 & 00.00 & 00.00 & 70.00 & 00.00 \\
\hline \multirow{4}{*}{$\begin{array}{l}\text { Streptococcus spp. } \\
(\mathrm{n}=10)\end{array}$} & Resistance & 00.00 & 00.00 & 70.00 & 100.00 & 00.00 & 00.00 \\
\hline & Less sensitive & 00.00 & 00.00 & 30.00 & 00.00 & 00.00 & 30.00 \\
\hline & $\begin{array}{l}\text { Moderate } \\
\text { sensitive }\end{array}$ & 30.00 & 30.00 & 00.00 & 00.00 & 30.00 & 70.00 \\
\hline & Highly sensitive & 70.00 & 70.00 & 00.00 & 00.00 & 70.00 & 00.00 \\
\hline \multirow{4}{*}{$\begin{array}{l}\text { E. coli } \\
(\mathrm{n}=10)\end{array}$} & Resistance & 00.00 & 00.00 & 00.00 & 30.00 & 00.00 & 00.00 \\
\hline & Less sensitive & 00.00 & 00.00 & 70.00 & 70.00 & 00.00 & 00.00 \\
\hline & $\begin{array}{l}\text { Moderate } \\
\text { sensitive }\end{array}$ & 30.00 & 30.00 & 30.00 & 00.00 & 30.00 & 70.00 \\
\hline & Highly sensitive & 70.00 & 70.00 & 00.00 & 00.00 & 70.00 & 30.00 \\
\hline
\end{tabular}

$\overline{\mathrm{GN}}=$ Gentamicin; AMP = Ampicillin; CIP = Ciprofloxacin; AMX = Amoxicillin; CTR = Ceftriaxone; ERY $=$ Erythromycin

From the results of the present study, it may be concluded that single infection is higher than mixed infection; the mixed bacterial infections are the major causes of sub-clinical mastitis in cows. Staphylococcus spp. Streptococcus spp. and E. coli, are established as the major etiological agents of sub-clinical mastitis in cows from the present study. Antibiogram results indicated that gentamicin, ciprofloxacin, and ceftriaxone in optimum doses would be the drug of choice to resolve the most cases of sub-clinical mastitis. Antibiotic sensitivity results suggested not to recommend amoxicillin, ampicillin for therapeutic uses against mastitis since isolated pathogens were resistant to these drugs.

\section{REFERENCES}

1. Anonymous (2003). Mastitis in dairy cows. Department of Animal Science, Faculty of Agricultural and Environmental Sciences, McGill University, Anne de Bellevue, Canada pp. 12.

2. Beveridge TJ (1999). Structures of gram-negative cell walls and their derived membrane vesicles. Journal Bacteriology 181: 4725-4733. 


\section{T. Hasan and others}

3. Boscos C, Stefanakis A, Alexopoulos CB and Samartzi F (1996). Prevalence of sub-clinical mastitis and influence of breed, parity, stage of lactation and mammary bacteriological status on goats. Journal of American Veterinary Medicine 2:1244-1247.

4. Bramely AJ (1996). Current concepts of bovine mastitis. 4th Ed. National Mastitis Council, Inc. Arlington, VA.

5. Chakrabarti A (2007). A textbook of Preventive veterinary medicine. $4^{\text {th }}$ edn., Kalyani Publishers, New Delhi. pp. 477.

6. Goswami P, Biswas S and Podder RC (2002). Isolation and antibiogram of bacterial isolates from clinical mastitis. Indian Journal of Animal Health 41: 52-54.

7. Gupta PD, Chanda A, Ray K and Mukherjee N (1992). Studies on bovine mastitis producing organisms and drug sensitivity of the isolates in West Bengal. Indian Journal of Animal Health 31: 71-73.

8. Islam MA, Rahman AKMA, Rony SA and Islam MS (2010). Prevalence and risk factors of mastitis in lactating dairy cows at Baghabari milk shed area of Sirajganj. Bangladesh Journal of Veterinary Medicine 8: 157-162.

9. Jha VC, Thakur PR and Yadav JN (1994). Bacterial species isolated from clinical bovine mastitis and their antibiotic sensitivity patterns. Veterinary Review Kathmandu 9: 21-23.

10. Kader MA, Samad MA and Saha S (2003). Influence of host level factors on prevalence and economics of subclinical mastitis in dairy cows in Bangladesh. Indian Journal of Dairy Science 56: 235-240.

11. Madut NA, Godir AEA, ElJalil IM (2009). Host determinants of bovine mastitis in semi-intensive production system of Kharfoum State, Sudan. Journal of Cell and Animal Biology 3: 71-77.

12. Misra PR. Roy PK and Das KL (1993). Bovine mastitis in Orissa: Predominant microflora and antibiotic sensitivity test pattern. Indian Journal of Dairy Science 46: 543.

13. Nazifi S, Haghkhah M, Asadi Z, Ansari-Lari M, Tabandeh MR, Esmailnezhad Z and Aghamiri M (2011). Evaluation of sialic acid and acute phase proteins (haptoglobin and serum amyloid A) in clinical and sub-clinical bovine mastitis. Pakistan Veterinary Journal 31: 55-59.

14. Nickerson SC and Boddie RL (1997). Mastitis prevention. Louisiana Agriculture 40: 24.

15. Prodhan MAM, Kamal AHM and Mahbub-E-Elahi ATM (1996). Prevalence of sub-clinical mastitis in cows of Baghabari Milk shed area. Bangladesh Veterinary Journal 30: 59- 61.

16. Rahman MA, Bhuiyan MMU, Kamal MM and Shamsuddin M (2009). Prevalence and risk factors of mastitis in dairy cows. Bangladesh Veterinarian 26: 54-60.

17. Rahman MM, Islam MR, Uddin MB and Aktaruzzaman M (2010). Prevalence of sub-clinical mastitis in dairy cows reared in Sylhet district of Bangladesh. International Journal of Bio Research 1: 23-28.

18. Roberson JR, Warnick LD and Moore G (2004). Mild to moderate clinical mastitis efficacy of intramammary amoxicillin, frequent milk-out, a combined intramammary amoxicillin, and frequent milk-out treatment versus no treatment. Journal of Dairy Science 87: 583-592.

19. Rosenberg JB, Love B and Patterson DL (2002). Bacterial cure and somatic cell count response of dairy cows with a positive California Mastitis Test at calving to therapy with cephapirin sodium. Veterinary Therapeutics 3: 381-386.

20. Sachin J and Suresh G (2006). Status of mastitis as an emerging disease in improved and periurban dairy farms in India. Annals of the New York Academy of Sciences 1081: 74-83.

21. Samad MA (1996). Poshu palon O Chikissavidya [In Bengali]. $1^{\text {st }}$ edn. LE Publications, Dhaka, Bangladesh.

22. Saxena RK, Dutta GN, Borah P and Buragohain J (1993). Drug susceptibility and treatment of bovine sub-clinical mastitis. Indian Veterinary Journal 70: 201-203.

23. Schalm OW, Carrol EJ and Jain NC (1971). Bovine mastitis. Lea and Febiger, Philadelphia, U.S.A.

24. Seegers H, Fourichon C and Beaudeau F (2003). Production effects related to mastitis and mastitis economics in dairy cattle herds. Veterinary Research 34: 475-491.

25. Seyoum T, Ameni G and Ashenafi M (2003). The prevalence of bovine mastitis, bacterial isolation and their susceptibility to antibiotics in Central Ethiopia. Bulletin of Animal Health and Production in Africa 51: 182-189.

26. Sharma N and Maiti SK (2010). Incidence, etiology and antibiogram of sub clinical mastitis in cows in durg, Chhattisgarh. Indian Journal of Veterinary Research 19: 45-54.

27. Shike DD, Keskar DV, Jagadish S, Bhalero DP and Sharma LK (1998). Sub-clinical and clinical mastitis in crossbred cows: Aetiology and antimicrobial sensitivity. Indian Veterinary Journal 75: 458-459.

28. Tuteja FC, Kapur MP, Sharma A and Sharma A (I993). Antibiogram of microorganisms isolated from bovine intramammarv infections. International Journal of Animal Science 8: 103-106.

29. Wallace JA, Stipetic K, Schukken YH, Dingwell RT, Baillargeon P, Bacic G and Leslie KE (2004). An evaluation of a treatment protocol for intramammary infections in early postpartum dairy cows based on a positive California Mastitis Test. Bovine Practice 38: 72-78. 